\author{
Alla MELNYK
}

\title{
STATE ENTREPRENEURSHIP \\ IN THE DEVELOPMENT OF REGIONS IN UKRAINE: A MATTER OF CHOOSING METHODS FOR ANALYSIS AND EMPIRICAL RESEARCH
}

\begin{abstract}
The problem was raised of the public entrepreneurship role as a factor affecting the development of the regions. The urgency of the research is due to the fact that the issue of state participation in the national and regional economies remains controversial in economic science. This is especially important for the countries with emerging markets. For Ukraine the importance of the research is peculiar because another wave of privatization is expected.

The author offered her method of analysis that complements the existing approaches to evaluating the effectiveness of the institutional phenomenon, in particular, the use of the methods for comparative analysis of the concentration of state business in the world countries and Ukraine, and assessment of state entrepreneurship functional load in specific regions. The empirical analysis is made, and the functions of public entrepreneurship formed for ensuring the regional development. The conclusion is made on the appearance of economic, social, environmental and political risks when making unreasonable decisions about the prospects for public entrepreneurship, and suggestions are substanti-
\end{abstract}

(C) Alla Melnyk, 2017.

Melnyk Alla, Dr. of Econ. Sciences, Prof., Ternopil National Economic University, Ukraine. 
ated for the selection of the criterial base for institutional changes in entrepreneurship development all through the regions.

\section{Key words:}

Entrepreneurship, public entrepreneurship, efficiency criteria of public entrepreneurship, functions of state entrepreneurship to ensure regional development.

JEL: R11.

\section{Introduction}

The selection of the research topic is prompted by the fact that the role of the state in national and regional economies has been the subject of ongoing discussions in the economic studies. This is particularly essential for countries with emerging markets. For Ukraine, which is regarded as one of them, the relevance of the research problem is justified by the fact that another wave of privatization is expected in the upcoming years. So far, the scientific evidence confirms that the change of ownership over the prior periods of privatization, bankruptcy and liquidation of many strong state-owned enterprises have affected regional economies ambiguously and contributed to the growth of unemployment and poor economic indicators. Moreover, the economic performance of state-owned enterprises has not been offset by the private sector.

\section{Brief literature review}

The theoretical framework of state-owned entrepreneurship, which can be used to further analyze the nature of state-owned entrepreneurship in the development of regions, is elaborated by E.G. Dolan, D.E. Lindsay (Dolan, Lindsay 1991), J.A.Schumpeter (Schumpeter 1982), F.A. Hayek (Hayek 2006), J.E. Stiglitz (Stiglitz 1977). The new approach to the role of state-owned entrepreneurship is presented in the papers by P.Armstrong (Armstrong 2015), 
N.Jones, S.Meintyre, I.Sturesson (Jones, Meintyre, Sturesson 2015); regional challenges of ownership reforms are considered by Yu. Kindzerskyi (Kindzerskyi 2010); the role of the public sector in the institutional support to national economy is defined by A. Melnyk, O.Dlugopolskyy (Melnyk, Dlugopolskyy 2008). Although the highlighted problem has been discussed in a number of earlier papers, no solutions appear to have been suggested for determining the role of state-owned entrepreneurship in regional development, which mostly can be explained by methodological limitations and insufficient information.

3. The objective of the article is to offer methodological insights into the matter of defining the role and functional implication of stateowned entrepreneurship in the development of regions, as well as to empirically assess this institutional phenomenon with regard to Ukraine's regions.

\section{Methods for analysis: a matter of choosing}

Since an existing lack of accurate statistics has an impact on the validity of analysis and evaluation carried out to determine the role of state-owned entrepreneurship at regional, national, and global levels, today, there is a need for sufficient data that could give the entire picture of state-owned enterprises' performance. On the other hand, there is no consensus among scholars and practitioners on how to define the terms "state sector», "state-owned entrepreneurship", and "state-owned enterprise", and there is also no international classification of business units owned and funded by the state.

In the economic literature and legal framework, state-owned entrepreneurship is viewed as economic and entrepreneurial activities of state-owned enterprises that facilitate the production of goods and provision of services (the supply of labour or other services) for economic agents (private enterprises and the general public). The basic institutional arrangement of state-owned entrepreneurship is a state-owned enterprise. The organizational and legal forms of stateowned entrepreneurship in Ukraine are as follows: state unitary enterprises (act as state-owned enterprises and state-run enterprises); state corporations (corporate state-owned enterprises); mixed ownership enterprises (Chumachenko 2001).

The presence of state-owned enterprises is considered to be justified by certain circumstances when: 1 ) it is impossible to achieve the macroeconomic 
optimum within the private sector (primarily in natural monopolies); 2) there is a necessity for maintaining low-return and capital-intensive enterprises that are unattractive to the private sector (Methodological guidelines from December 22, $2012)$; 3) there is a need for control over enterprises that are essential for the national economy; 4) there is a necessity to use state-owned enterprises as a tool to regulate various sectors of the national economy; 5) there is a necessity for targeted regional policies.

Hence, in order to determine the feasibility of the development of stateowned entrepreneurship, its efficiency and effectiveness in terms of regional economic growth, the problem of choosing methods for analysis has to be addressed. Several sources should be taken into consideration as background material, namely: «Methodological guidelines on the application of criteria for defining the effectiveness of management in the state sector» (Methodological guidelines from December 22, 2012) and «Guidelines for calculating the percentage of the state sector as part of the economy» (Guidelines from December 22, 2012).

According to the former source, the following criteria for research and evaluation are to be employed: 1) socio-economic or non-commercial indicators, notably: the average staffing number; backdated salaries; social overhead costs; 2) commercial indicators: net operating income (revenue) from sales and net profit (loss); the part of the profit transferred to the budget; dividends on shares owned by the state in the authorised capital of economic entities; 3) indicators that reflect innovation and investment activities of state-owned enterprises: value of assets; cost of equity; estimated capital investment; amount of capital depreciation; 4) financial indicators: return on assets; operating profitability; overall / absolute liquidity ratio; equity funds ratio (Methodological guidelines from December 22, 2012).

However, applying the described methods in the field of regional research has some shortcomings: firstly, because of its sectoral focus; secondly, due to the want of accurate statistics on Ukraine's regions, and the need of a rather time-consuming process of selecting relevant data from the Unified State Register of Enterprises and Organizations of Ukraine (USREOU); thirdly, for lack of indicators that reflect the contribution of state-owned enterprises to economic and social development of regions. As part of this regional analysis, exceptions are to be made for the indirect use of the following indicators that are extracted from primary reports: index of employment, backdated salaries, and estimated capital investment.

In accordance with «Guidelines for calculating the percentage of the state sector as part of the economy» (Methodological guidelines from December 22, 2012), the indicators used in the analysis include: the number of entities; net operating income (revenue) from sales of goods and services; net profit (loss); average current and noncurrent assets (at the beginning and at the end of the year); average staffing number; value added; estimated capital investment. 

a Matter of Choosing Methods for Analysis and Empirical Research

De facto, according to the Unified State Register of Enterprises and Organizations of Ukraine, the State Statistic Service of Ukraine issues statistical bulletins on regional performance that provide only the data on the number of entities in the USREO in terms of their legal form of organization, which allows us to computationally determine the number and ratio of state-owned entities.

Taking into account some of the limitations of statistical information and advantages of the reviewed methods, empirical assessments on the role of stateowned entrepreneurship in the development of Ukraine's regions have been carried out, based on the methods of system, structure-function, and comparative analysis, computational method and statistical sampling.

For the purpose of this study, the author assumes that state-owned entrepreneurship should be examined from two angles: 1) as a process of establishing state-owned enterprises and managing their legal forms of organization; 2) as a form of organizational and commercial activities of state-owned enterprises for the production of goods and provision of services to economic units embedded within high-order systems.

\section{Empirical assessment on the development of state-owned entrepreneurship in Ukraine's and regional economies}

According to the data of the Unified Register of State-Owned Assets, in Ukraine in 2015, there were 3350 state-owned enterprises, and the State owned approximately 650 blocks of stock in the authorized capital of economic units (Ministry of economic development and trade of Ukraine 2016). The share of state-owned enterprises in Ukraine's GDP is estimated to be $37-40 \%$, which is higher than in most of the developed countries of the world (in Canada, the United Kingdom, and Italy about 15\%; in the USA and Germany almost $20 \%$; in Poland $25 \%$ ). In Ukraine, 100 high-scale companies account for $80 \%$ of stateowned assets.

The comparative analysis confirms that within the period of 2009-2015 in the economies of the developed countries there was a tendency towards decreasing the number of state-owned enterprises, whereas in the developing countries an increase was observed. In Ukraine, the latter tendency does not appear to have been a case, because in 2012-2015, as well as in previous years (2001-2011), there was a stable decline in number of state-owned enterprises.

For instance, from 2001 to 2015 the total number of state-owned enterprises went down by 1.79 times, while the total number of economic entities in the USREOU increased by 1.59 times. Some differences are observed in the dis- 
ISSN 2519-4070

tribution of enterprises. In particular, in Ukraine, these include agriculture, forestry, fishing industry, manufacturing industry, real estate activities, construction, wholesale and retail trade, automotive maintenance, temporary accommodation and arrangements for feeding, transport and warehousing, financial and insurance activities; whereas in the OECD countries, they occur in real estate activities, transport, warehousing, postal and courier service, electric, gas, vapour and conditioned air service, raw material industry, agriculture, forestry, fishing industry, financial activities, telecommunications.

Based on [Methodological guidelines from December 22, 2012], [Ministry of economic development and trade of Ukraine 2016] and on the relevant calculations presented, the following characteristics that reflect the participation of state-owned entrepreneurship in Ukraine's economic performance can be determined. In 2015 , state-owned enterprises, constituting $0.6 \%$ of the total number of entities (1.5\% in 2005), provided $15.8 \%$ of job vacancies $(21.0 \%$ in 2005$), 9.3 \%$ of capital investments (14.3\% in 2005), $11.4 \%$ of net income from sales of goods, services and labour produced by entities of the state sector (12.7\% in 2005).

Almost all regions showed a decrease in the percentage of state-owned enterprises in the total number of economic units. With the average fall in the number of Ukraine's state-owned enterprises being about 1.79 times in 20012015, in Donetsk region it amounted to 2.25 times, in Ivano-Frankivsk region to 2.34 times, in Mykolaiv region to 2.32 times, in Luhansk region to 2.73 times, in Ternopil region to 2.55 times, in Khmeknytskyi region to 2.86 times. The only exception is Kyiv, where the number of state-owned enterprises rose by 1.02 times $^{1}$. Of 25 regions analyzed (the Crimea and Sevastopol are not included), 14 are characterized by a lower percentage compared to the average ratio of stateowned enterprises in the total number of Ukraine's economic units listed in the USREOU. It is only in 4 regions (the city of Kyiv, Zaporizhzhia, Kyiv, and Luhansk regions), that the total number of economic units in the USREOU went up rather than down, indicating that in most regions the decline in the number of state-owned enterprises was not offset by the growing number of private sector entities.

The highest number of state-owned enterprises is concentrated in Dnipropetrovs'k, Donetsk, Kyiv, Lviv, Kharkiv and Zaporizhzhia regions where powerful industrial production is located. Such large-scale enterprises as Antonov, Pivdenmash, Khartron, Turboatom, Electrotyazhmash, and Azovmash provide a strategic function in the development of cities and agglomerations. $81 \%$ of the biggest state-owned enterprises are concentrated in the city of Kyiv (NJSC Naftogaz of Ukraine, SE Ukrzaliznytsia, SE Energy Market, SE Energoatom, etc). The conglomeration of state-owned enterprises in the mentioned regions allows the regional centres to perform some of the metropolitan functions: innovative (Kharkiv, Kyiv, Lviv, Odesa); logistic (Odesa); economic (Kyiv, Dnipro); transpor-

${ }^{1}$ Calculated by the author based on (The State Statistics Service of Ukraine 2016) 
tational (Lviv, Kyiv, Odesa, Dnipro, Kharkiv); investment (Kyiv); business (Kyiv, Dnipro).

The empirical studies carried out as part of the research in the context of regions allow us to undertake the structure-function analysis and to identify other functions of state-owned entrepreneurship for economic and social development in Ukraine's regions: 1) financing regional growth (6 state-controlled banks and their branches in regions); 2) state support to business and SMEs through financing innovation projects (the Agrarian Fund of Ukraine, Ukrainian Bank of Reconstruction and Development); 3) security deposit guarantee (State Savings Bank of Ukraine and its branches in regions); 4) financing state and private projects aimed at the development of high value-added industries, attracting foreign credits (Ukreximbank); 5) price control policy for products that are subject to state regulation (State Food and Grain Corporation of Ukraine); 6) land market regulation (The Agrarian Fund of Ukraine).

There are some vital challenges for economic growth of Ukraine's regions, including through state entrepreneurship, that demand immediate attention, namely: establishment of basic institutional arrangements which greatly increases the difficulty of achieving the goals of social and economic development, especially at a time of the collapse of large industrial, research and manufacturing complexes acting as a backbone to some regions, resulted in the breakdown of the existing institutional structure and the emergence of non-competitive enterprises; in some regions, there is a failure to leverage resources with the involvement of private businesses for structural reforms; capital consolidation during «fuzzy» ownership and through business takeovers, conglomerate consolidation of capital in certain regions, accompanied by the dispersal of activities and resources between numerous areas, diminish the possibility of achieving a synergetic effect from concentration and a favourable environment for innovations (Kindzerskyi 2010); reform imbalances of various components of property rights, the neglect of economic parameters of certain regions, which had a destructive effect not only for production, but also for regional job markets, social infrastructure, life-support conditions and social protection in regions; in certain regions, preservation of old industrial structures and technological paradigms, poor infrastructure that hinders the whole process of economic growth in regions, unwillingness of the private sector to sacrifice dividends for capital investment or to negotiate contracts that have a strongly-marked external nature. The lack of response to the challenges from the government and state entrepreneurship create economic, social, ecological and political risks. 


\section{Considerations on the improvement of methods for analysis}

A complete assessment of state-owned entrepreneurship as a factor for regional development requires the reflection of its nature: 1 ) as a subsystem in regional entrepreneurship; 2) as a subsystem in regional economy; 3 ) as a subsystem in economic and social development of regions. The latter implies the need to assess the functional role of state-owned entrepreneurship. It is the function of state-owned entrepreneurship, primarily, in terms of institutional support to regional development that the above methods of analysis do not address. This absence of methods leads to inappropriate administrative decisions on transfer of ownership in the state sector, and to subjectivity, that ignores the necessary criteria.

The need to improve methods for analysis of state-owned entrepreneurship as a factor for regional development, and to evidence its benefits stems from the theoretical points outlined in the reviewed papers (Dolan, Lindsay 1991; Schumpeter 1982; Hayek 2006; Stiglitz 1977) and other theoretical studies (Chumachenko 2010), according to which the current status of the research object (SOEs) can be seen based on the research of structure and specific functions, and a model of state-owned entrepreneurship should be considered as multifunctional.

Multifunctionality of state-owned entrepreneurship means that besides the main synthetic function, that is, the function of the leading institution of regional economic development, it is intended to ensure economic security and integrity of a region, its balanced and sustainable development, an increase of regional economic competitiveness, a creation of favourable environment for private entrepreneurship, employment and, along with a positive structural shift, promotion of environmental issues.

Accordingly, to address these problems, it is possible to propose methods of comprehensive analysis, which include criteria, indicators (performance indicators), and functions of state-owned entrepreneurship in institutional support to economic and social development of a region. These criteria include: 1) restructuring in favour of high value-added industries influenced by SOEs; 2) involvement of SOEs in the production of GRP; 3) the economic impact of SOEs on the real economy's growth; 4) involvement of SOEs in employment; 5) investment made by SOEs to a region's economy; 6 ) innovative development of a region; 7) contribution of SOEs to long life-cycle production; 8) impact of SOEs on system / city-forming and agglomeration forming; 9) the ability of SOEs to create poles of economic growth and economic clusters; 10) impact of SOEs on corporate business; 11) impact of SOEs on small and medium entrepreneurship; 12) involvement of SOEs in the implementation of strategies and target pro- 
grammes of regions, each of which can be reflected in regional statistics or announced for statistical monitoring.

This will eliminate the disadvantages of sector-specific (industry-specific) approach to the assessment of the role and effectiveness of state-owned entrepreneurship, and establish an information framework that could enhance the responsibility of local authorities for integrated economic and social development, as well as economic security, which is vital under conditions of decentralization.

\section{Conclusions}

1) State-owned entrepreneurship should be viewed as an essential factor of regional development. As a system, it is now, and should remain, an important subsystem in entrepreneurship, in regional economy and in institutional support. As a process, in countries with emerging economies and in Ukraine, state-owned entrepreneurship is characterized by a turbulence of its qualitative components, which is caused by both internal and external reasons, and also has generated a number of challenges and risks for regional development.

2) As a subsystem in regional economic development, state-owned entrepreneurship should ensure its stability, balance and regulatory functions. As a process, it should focus on economic, social and institutional effectiveness.

3) Today, decision-making on involvement of state-owned entrepreneurship in regional development and in management is based on production (industry-specific) criteria of effectiveness and fiscal goals, while neglecting a synergetic effect for economic, social and institutional development of a region. This fact requires development of methods for assessment and analysis of its involvement, and also relevant information support. The author proposed methods that are based on a combination of industrial and regional interests, focused on the multifunctional role of state-owned entrepreneurship and can be used in public and regional administration.

4) A managerial decision-making process should include: a diverse choice of alternatives depending on the status (sustainable or unsustainable) of development, historical experience, possible manifestations of «Wagner's phenomenon» (Wagner 1958), a set of criteria needed to achieve «a social compromise» in regional communities. 


\section{References}

1. Dolan E.G., Lindsay D.E., 1991, Rynok: mikroekonomicheskaia model [Market: Microeconomic Model], Saint Petersburg, 486 p.

2. Schumpeter J.A., 1982, Teoriia ekonomicheskogo razvitiia [Theory of Economic Development], Progress, Moscow, $436 \mathrm{p}$.

3. Hayek von F.A., 2006, Pravo, zakonodatelstvo i svoboda: Sovremennoe ponimanie liberalnykh printsypov spravedlivosti i politiki [Law, Legislation and Liberty: A New Statement of the Liberal Principles of Justice and Political Economy], IDISES, Moscow, 644 p. [in Russian].

4. Stiglitz J.E.,1977, Ekonomika gosudarstvennogo sektora [Economics of the Public Sector: translated from English], MSU: INFRA-M, Moscow, 720 p.

5. Armstrong P., 2015, Corporate governance and state-owned enterprises, Commentary. Ethical boardroom, http://www.ifc.org/wps/wcm/connect/ 1299668047f4ee8bae58ff299ede9589/EB_IFC_Phil_Armstrong.pdf?MOD=A JPERES.

6. Jones N.C., Meintyre S., Sturesson I., 2015, State-owned enterprises. Catalyst for public value creation? PWC Publications, pp.1-47.

7. Kindzerskyi Yu., 2010, Problemy rozbudovy instytutu vlasnosti u svitli modernizatsii ekonomiki [The Challenges of Ownership Building through the Prism of Modernization], Visnyk KNTEU - Bulletin of KNTEU, No. 4, pp. 1523.

8. Melnyk A. F., Dluhopolskyy O., 2008, Publichnyy sektor i derzhavna polityka v demokratychnomu suspilstvi [The Public Sector and Government Policies in a Democratic Society], Ekonomichna dumka, Ternopil, 268 p.

9. Derzhavnyy sector ekonomiky. Derzhavne pidpryemnytstvo [The State sector of economy. State-owned entrepreneurship], http://pidruchniki.com/ 1146071838734/ekonomika/derzhavniy_sektor_ekonomiki_derzhavne_pidpriyemnitstvo (15.10.2016).

10. Chumachenko N. G., 2001, Organizatsionnyi mekhanizm upravleniia gossektorom promyshlennosti [Institutional Framework for the State Industrial Sector], Upravlenie ekonomikoi perekhodnogo perioda [Governance in a Transition Economy], IEI NAS of Ukraine, Donetsk, p. 4-14.

11. Metodychni rekomendatsii zastosuvannia kryteriiv vyznachennia efektyvnosti upravlinnia obiektamy derzhavnoi vlasnosti (Nakaz Ministerstva ekonomichnoho rozvytku i torhivli № 1466 vid 22.12.2012) [Methodological guidelines on the application of criteria for defining the effectiveness of management in 
the state sector (The Order of the Ministry of economic development and trade of Ukraine from December 22, 2012 of No. 1466)].

12. Pro zatverdzhennia Metodyky vyznachennia chastky derzhavnoho sektoru u skladi ekonomiky (Nakaz Ministerstva ekonomichnoho rozvytku i torhivli № 1466 vid 22.12.2012) [On the Approval of the Guidelines for calculating the percentage of the state sector as part of the economy (The Order of the Ministry of economic development and trade of Ukraine from December 22, 2012 of No. 1466)].

13. Pytoma vaha derzhavnoho sektoru $v$ ekonomitsi, 2016 [The percentage of the State Sector in the Economy], the Ministry of economic development and trade of Ukraine, http://me.gov.ua/Documents/List?lang=uk-UA\&tag= Upravlinnia DerzhavnimSektoromEkonomikils (15.10.2016).

14. Rehiony Ukrainy 2015, 2016, [Regions of Ukraine 2015], the State Statistics Service of Ukraine, p. 19-41.

15. Wagner A., 1958, Three Extracts on Public Finance, [in]: Wagner A., Musgrave R., Peacock A. (eds.), Classics in the Theory of Public Finance, Macmillan, N.Y. 